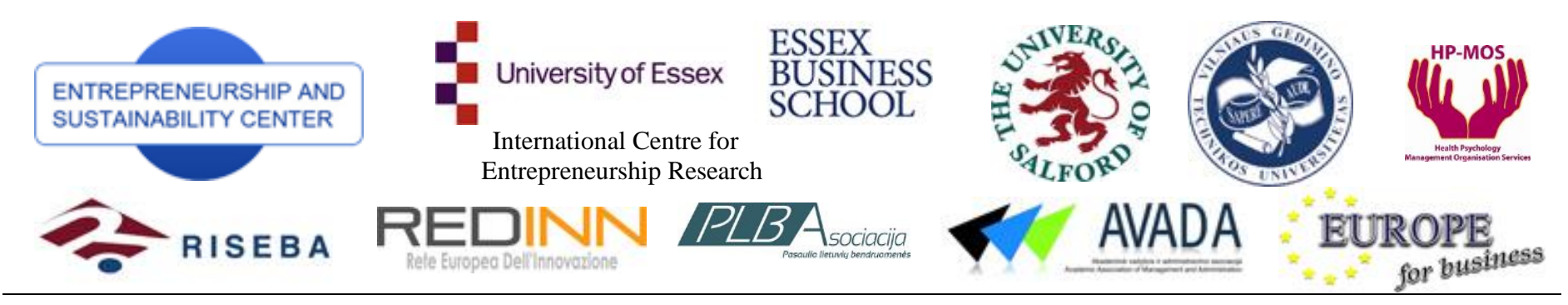

ENTREPRENEURSHIP AND SUSTAINABILITY ISSUES

ISSN 2345-0282 (online) http://jssidoi.org/jesi/aims-and-scope-of-research/

\title{
SUSTAINABLE ENTREPRENEURSHIP VIA ENERGY SAVING: ENERGY HARVESTER EXPLOITING SEEBECK EFFECT IN TRADITIONAL DOMESTIC BOILER
}

\author{
Stefano Barberis ${ }^{1}$, Lorenzo Di Fresco ${ }^{2}$, Vincenzo Alessandro Santamaria ${ }^{3}$, \\ Alberto Traverso ${ }^{4}$ \\ ${ }^{1,2,4}$ University of Genoa, Department of Mechanical Engineering, \\ Via Montallegro, 1, 16145 Genova, Italy \\ ${ }^{3}$ TechCom Srl, Via Argonne 5r, 16146 Genova, Italy \\ E-mails: ${ }^{1}$ Stefano.barberis@edu.unige.it; ${ }^{2}$ lorenzo.difresco@unige.it; ${ }^{3}$ Vincenzo.alessandro.santamaria@gmail.com; \\ ${ }^{3}$ Alberto.traverso@unige.it
}

Received 20 September 2014; accepted 10 November 2014

\begin{abstract}
In this paper, energy saving solutions are being elaborated, i.e. A system to harvest waste heat and convert it into electrical energy is presented; such a system is based on thermoelectric generators (teg) modules exploiting the seebeck effect. A technical and economic feasibility study of the system is presented, the most convenient applications of thermal energy residuals recovery in residential environment (detached house, condos, isolated off-the grid house) are evaluated according to the electrical supply of typical domestic low consumption devices (i.e. Led lighting); the total yearly production of thermoelectric generator is considered in different techno-economic scenarios. ${ }^{1}$
\end{abstract}

Keywords: sustainable entrepreneurships, energy saving, Seebeck effect

Reference to this paper should be made as follows: Barberis, S.; Di Fresco, L.; Santamaria, V.A.; Traverso, A. 2014. Sustainable entrepreneurship via energy saving: energy harvester exploiting seebeck effect in traditional domestic boiler, Entrepreneurship and Sustainability Issues 2(2): 86-97.

DOI: http://dx.doi.org/10.9770/jesi.2014.2.2(4)

JEL Classifications: R11, 04, 031, M1, Q4

\section{Introduction}

Sustainable entrepreneurship in business and household domain requires innovative energy solutions (Tvaronavičienė 2012; Balkienė 2013; Laužikas, Mokšeckienė 2013; Mačiulis, Tvaronavičienė 2013; Vosylius et al. 2013; Raudeliūnienè et al. 2014; Baublys et al. 2014; Caurkubule, Rubanovskis 2014; GarškaitèMilvydienė 2014; Litvaj, Poniščiaková 2014; Kaminskienė et al. 2014; Prause 2014; Rakauskienė 2014; Tvaronavičienė et al. 2014; Tvaronavičienè 2014; Vasiliūnaitė 2014). Thermoelectric conversion may be defined as the result of a process by which heat and temperature gradient can be converted into electricity through the use of a thermo-electric generator (TEG) exploiting the Seebeck effect. Thanks to this effect a thermal gradient formed between two dissimilar conductors produces a voltage (Seebeck 1825).

\footnotetext{
${ }^{1}$ The authors want to acknowledge Francesco Roncallo, graduated student at University of Genoa, for his contribution to this research activity.
} 
This effect can be used for energy saving, as exploited by energy harvester devices recovering waste heat or exploiting the natural thermal gradients available in the environment to produce electricity. At the heart of the thermoelectric effect is the fact that a temperature gradient in a conducting material results in heat flow; this results in the diffusion of charge carriers. The flow of charge carriers between the hot and cold regions in turn creates a voltage difference.

In 1834, Jean Charles Athanase Peltier discovered that running an electric current through the junction of two dissimilar conductors, depending on the direction of the current, could cause it to act as a heater or cooler. The heat absorbed or produced is proportional to the current, and the proportionality constant is known as the Peltier coefficient. Today, due to the knowledge of the Seebeck and Peltier effects, thermoelectric materials can be used as heaters, coolers and generators (TEGs) (Bell 2008). Ideal thermoelectric materials have a high Seebeck coefficient (the most important coefficient to evaluate TEG potential as it correlates thermal gradient with the produced voltage), high electrical conductivity, and low thermal conductivity (Nolas et al. 2001).

Low thermal conductivity is necessary to maintain a high thermal gradient at the junction. Standard thermoelectric modules manufactured today consist of $\mathrm{P}$ - and $\mathrm{N}$-doped bismuth-telluride semiconductors sandwiched between two metallized ceramic plates. The ceramic plates add rigidity and electrical insulation to the system. The semiconductors are connected electrically in series and thermally in parallel. Thermoelectric conversion is nowadays strongly exploited in electronics and computer industry, using micro-TEG generator in order to make wireless sensor and similar devices totally power self sustained (Harb 2011; Vuller et al. 2009). One of the most common applications is the use of thermoelectric generators on gas pipelines providing electricity to the remote sensors monitoring the conduits, but they can be applied in a variety of applications (Murugavel 2008).

Thermoelectric generators are ideally used for small applications where other heat recovery system like ORC turbine or Stirling engines, which are bulkier, would not be possible, thermoelectric generators are more reliable and have a smaller chance of breaking over time and use. Spacecraft are a typical example of an application where maintenance is next to impossible after launch. TEGs are also used as remote and off-grid power generators for isolated sites (Nuwayhid et al. 2003). They are the most reliable power generator in such situations as they do not have moving parts (thus virtually maintenance free), work day and night, perform under all weather conditions, and can work without battery backup.

Cars and other ICE vehicles produce waste heat (in the exhaust and in the cooling agents) (Wang et al. 2013; Chien-Chou Weng and Mei-Jiau Huang 2013). Harvesting that heat energy, using a thermoelectric generator, can increase the fuel efficiency of the car. Waste heat is freely available in many other circumstances, such as in industrial processes and in heating (wood stoves, outdoor boilers, cooking, oil and gas fields, pipelines, and remote communication towers) (Champier et al. 2011; Champier et al. 2010; Bianchini et al. 2014).

Again, the waste heat can be reused to generate electricity. Since TEGs suffer from low electrical conversion efficiency, they are suitable for energy harvesting applications rather than large size electrical generation. In this paper an innovative TEG device based on commercial low cost Peltier cells and called qb_HOT is presented; this generator is able to exploit thermal gradient between the air environment and the flue chimney of traditional gas boiler or biomass stove suitable for heat generation in detached houses and condos as well as in alpine huts, mountain dew or off-the-grid isolated houses. The potential of this generator is evaluated in different scenarios and studying its production related to different possible consumption profiles and application. 


\section{NOMENCLATURE}

$\Delta \mathrm{T}$

DC

DHW

PV

TE

TEG

\section{Subscripts}

$\mathrm{c}$

$\mathrm{h}$

$\mathrm{t}$

teg
Thermal Gradient

Direct Current

Domestic Hot Water

Photovoltaic

Thermo - Electric

Thermo - Electric Generator

\section{2. qb_HOT: an innovative low cost TEG}

In a TE module, an electric voltage is generated between two semiconductors exposed to a temperature difference. Typical TE modules (also named Seebeck or Peltier cells) are composed by a set of semiconductor components formed from two different materials. As shown in Figures 1 and 2, these components are connected thermally in parallel and electrically in series.
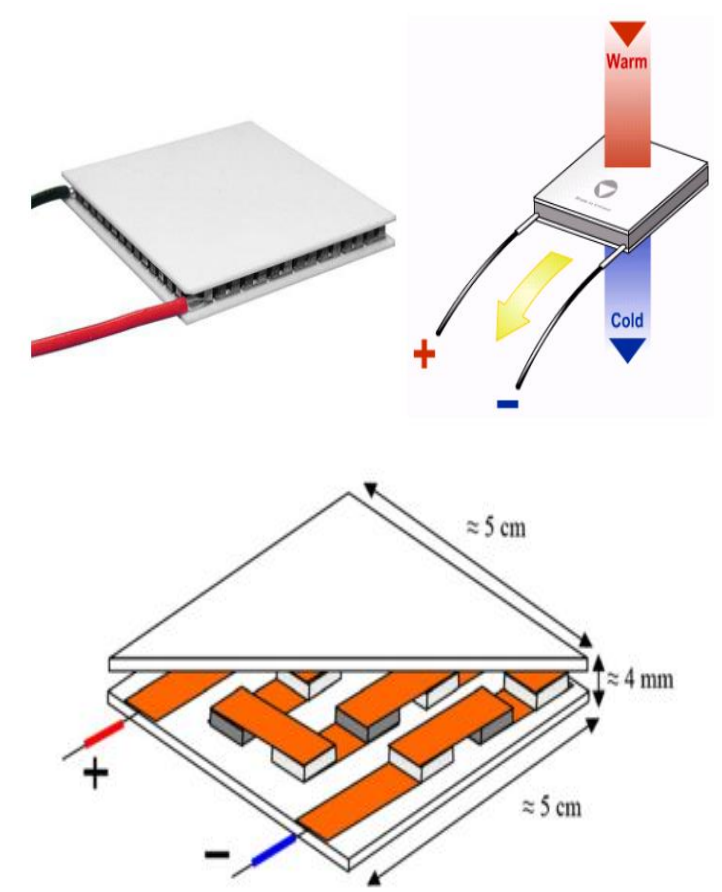

Fig.1. Structure and typical sizes of a Seebeck Cell (under) and its functioning principle (above)

Source: Seebeck (1825)

Two ceramic plates are stuck on each side for electrical insulation. Semiconductors are divided, depending on the material they are made of, into P-type and N-type components (Figure 2). 


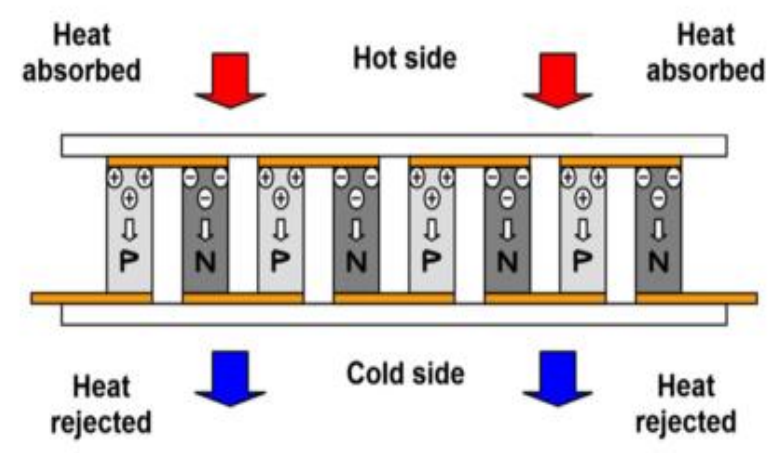

Fig.2. Working Scheme of a Seebeck Cell

Source: Seebeck (1825)

When heat flows through the cell, the N-type components are loaded negatively (excess of electrons) and P-type components are loaded positively (default electron), resulting in the formation of an electric flow. Materials wide available on the market at a reasonable price with thermoelectric properties suitable for ambient temperature applications are Bismuth Tellurid $\left(\mathrm{Bi}_{2} \mathrm{Te}_{3}\right)$ and Bismuth Tin $(\mathrm{BiSn})$.

\section{1.qb_HOT Concept: Design Parameters}

For this research, we designed and built a TEG (see Figure 3) based on low cost material: four $\mathrm{Bi}_{2} \mathrm{Te}_{3}$ modules for thermoelectric cooling applications from Thermonamic Co. Ltd. are used coupled to a classical heat sink for computer application, a conductive patch on the hot side in order to optimize the heat recovery towards the cell.

The specifications of the modules are reported here below (Thermo-electric module generator - TEP 1-1264-15 Technical Data Sheet):

- Part Number: TEP 1-1264-15

- Size: $4 \mathrm{~mm}$ x $4 \mathrm{~mm}$ x $3.3 \mathrm{~mm}$

- Life Expectancy: 200000 hours

Looking at the performances they are linked to the Hot Face temperature of the cell:

Table 1. Operating Performances

\begin{tabular}{|l|c|}
\hline Hot Side Temperature $\left({ }^{\circ} \mathrm{C}\right)$ & 300 \\
\hline Cold Side Temperature $\left({ }^{\circ} \mathrm{C}\right)$ & 30 \\
\hline Open Circuit Voltage $(\mathrm{V})$ & 9.4 \\
\hline Matched Load Resistance $(\mathrm{ohms})$ & 2.8 \\
\hline Matched load output voltage $(\mathrm{V})$ & 4.7 \\
\hline Matched load output current $(\mathrm{A})$ & 1.56 \\
\hline Matched load output power $(\mathrm{W})$ & 7.3 \\
\hline Heat flow across the module $(\mathrm{W})$ & $\approx 152$ \\
\hline Heat flow density $\left(\mathrm{W} \mathrm{cm}^{-2}\right)$ & $\approx 9.5$ \\
\hline $\begin{array}{l}\text { AC Resistance }(\mathrm{ohms}) \mathrm{Measured} \\
\text { under } 27^{\circ} \mathrm{C} \text { at } 1000 \mathrm{~Hz}\end{array}$ & $1.3 \sim 1.8$ \\
\hline
\end{tabular}

Source: Thermonamic Co. (2014) 

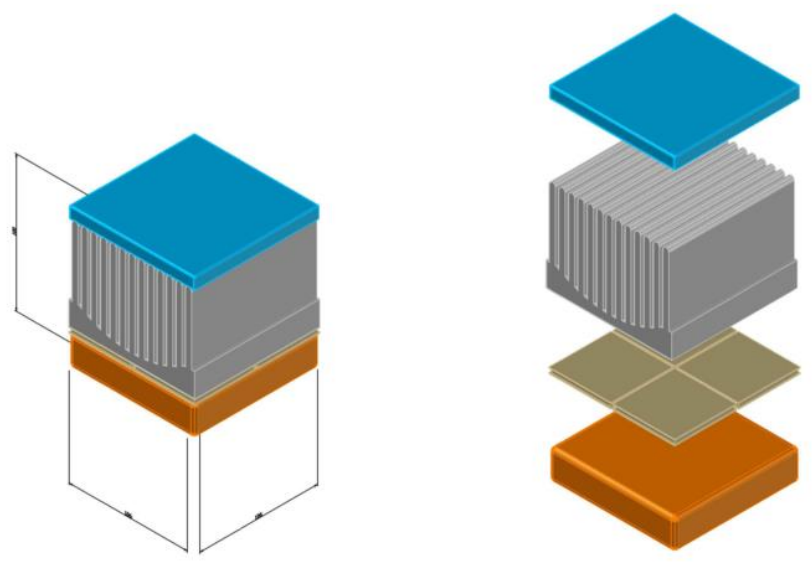

Fig.3. qb_HOT Structure

Source: Thermonamic Co. (2014)

It is worthy to underline that the maximum load output power of these cells is about 7-8 W, even if it depends on the available thermal gradient, as it can be seen in fig. 4. In our test conditions, the cell was able to produce 1-2 $\mathrm{W}$ of electrical power.

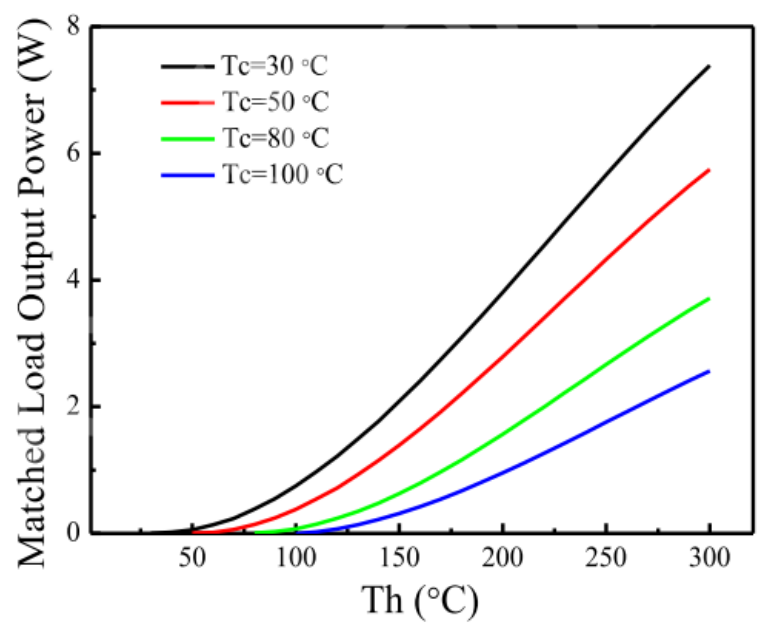

Fig.4. Performance Curves

Source: Thermonamic Co. (2014)

\section{2. qb_HOT possible configurations}

One of the most innovative features of qb_HOT is its compact and modular size that allows its use for different purposes with no limitations for mobility.

\section{a) qb_HOT portable charger}

In its basis configuration, qb_HOT includes, as reported in Figure 3: an energy harvester for outdoor dockings application, making possible to produce power wherever a thermal gradient or waste heat are present.

This device has a maximum power of $10 \mathrm{~W}$ and, coupling it with a USB plug, it will be able to charge different electronic devices with low voltage electric supply (i.e. mobile phone, smartphone, mp3 player...) just exploiting a thermal gradient available all around the user. This kind of configuration could be also integrated with a little PV cell (Figure 5 - left), in order to increase the power production of the charger or with a little 
solar mirror concentrator (Figure 5 - right) in order to increase the thermal gradient exploitable by the thermoelectric cell and improve the power potential of the TEG.
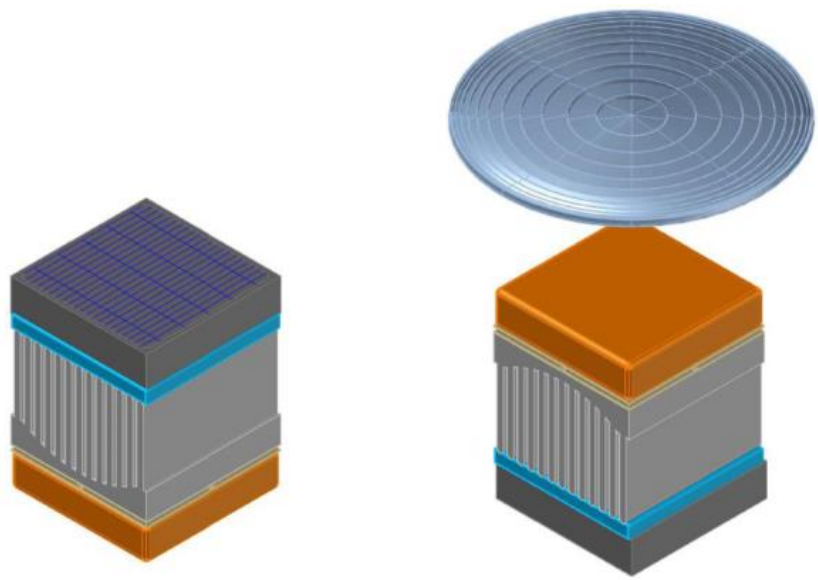

Fig.5. qb_HOT Mobile Charger Possible Integration

Source: Thermonamic Co. (2014)

\section{b) belt_HOT}

In order to exploit waste heat from the flue gas chimney of a boiler fed by any fuel (biomass, pellet, oil, gas...), a group of qb_HOT TEGs can be organized like in fig.6, putting them all around a belt capable to integrate from 15 to 150 TEG modules according to the diameter of the chimney. This kind of configuration extends the power potentiality to $20-250 \mathrm{~W}$ for each belt and it is worthy to underline that it's possible to install a certain number of belt_HOT on a single chimney according to its length.
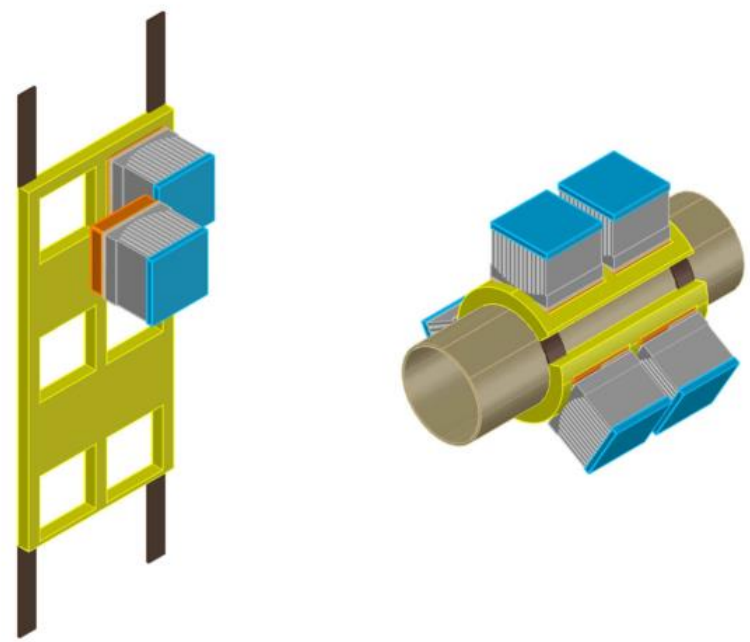

Fig.6. belt_HOT Energy Harverster for Flue Gas Chimney

Source: Thermonamic Co. (2014)

\section{Qb_Hot possible exploitation}

Three different belt_HOT application scenarios were analyzed:

- detached house with traditional $20 \mathrm{~kW}_{\mathrm{t}}$ natural gas domestic boiler; 
- condo heated by a $500 \mathrm{~kW}_{\mathrm{t}}$ natural gas boiler;

- $\quad$ alpine hut with a $50 \mathrm{~kW}_{\mathrm{t}}$ wood biomass boiler.

In all these scenarios the potential power producibility of the TEG is evaluated as well as the related thermal consumption, according to the different purposes of each scenario and using the correlation described by Hsu et al. 2011, which introduces a relationship with the measured Thot and Tcold and the effective $\Delta \mathrm{T}$ across the TE cell.

$$
\Delta \mathrm{T}_{\mathrm{teg}}=0.8742\left(\mathrm{~T}_{\mathrm{h}}-\mathrm{T}_{\mathrm{c}}\right)(1)
$$

The presence of a boost high efficiency DC-DC ultralow voltage step-up converter and power manager is taken into account according to its typical conversion efficiency of 85-90\% (OnSemi Conductor 2014; Champier et al. 2011).

Hence, a total correction factor of the power producibility can be evaluated approximately at $75 \%$ to correct the estimated values considered from the TE cell technical data sheet (Thermonamic Co. 2014).

\subsection{Detached house}

In a single family detached house, heat and domestic hot water (DHW) are provided by a traditional noncondensing $20 \mathrm{~kW}_{\mathrm{t}}$ gas natural boiler. These kind of boilers evacuate flue gas from their chimney (typical diameter $10 \mathrm{~cm}$ ) at a temperature of about $100-120^{\circ} \mathrm{C}$, so a thermal gradient of $80-100^{\circ} \mathrm{C}$ can be exploited in winter season by the belt_HOT TEG.

Two different options are analyzed: in the first one the power produced by the belt_HOT is used to feed the auxiliary systems of the boiler (circulating pumps, led lighting, fan in the chimney etc...), making the boiler able to work without being connected to the house electrical distribution grid. In the second one, the electricity produced by thermoelectric generator is used to supply power to a plug in docking station. Such docking station could be installed in the kitchen, and used to recharge typical house electrical devices, which don't require high voltage supply: vacuum cleaner, smartphone, battery charger, cordless phone, etc. It can be also used to feed garden LED lighting for security purposes during the night. Basing on chimney geometry, it is supposed to use a belt_HOT realized coupling three rows of TEG with 7 cell per row.

\subsubsection{Autonomous Boiler}

According to the Italian technical normative UNI 10348, the electrical power required by the auxiliary systems of a boiler of such this size can be evaluated in about $90-150 \mathrm{~W}$ (Italian Technical Normative... 1993) and the boiler has an operating period supposed in 2000 hours/year, related to a classical intermediate Italian climatic zone (Table 2) (Italian Governmental Decree... 1993).

Basing on such power request and on the exploitable thermal gradient $\left(80-100^{\circ} \mathrm{C}-\right.$ Figure 4$)$, it is supposed to install 6 belt_HOTs all along the evacuating piping: one just at the beginning of the pipe (where it is connected with the boiler), four in the central area and the last one at the chimney.

Table 2. belt_HOT application to make energy autonomous a boiler in a detached house

\begin{tabular}{|c|c|}
\hline belt_HOT configuration & 6 belt made by 21 TEG cells \\
\hline Total Pmax installed & $1 \mathrm{~kW}$ \\
\hline Power Output with $\Delta \mathbf{T}=\mathbf{8 0}^{\circ} \mathbf{C}$ & $100-150 \mathrm{~W}$ \\
\hline Total Year Energy Saving & $200 \mathrm{kWh}-40 €$ \\
\hline
\end{tabular}

Source: Italian Technical Normative...(1993) 
Such configuration, coupled with a battery to harness the overproduction, guarantees a continuous production of $100 \mathrm{~W}$ in these operating condition with a Pmax estimated in about $140 \mathrm{~W}$. The power required by the auxiliaries during the operating time (2/3 of the total amount is required by the hot water circulating pump) is guaranteed as it is simultaneously produced by belt_HOT.

\subsubsection{Docking Station and LED lightning}

The power produced by the four belt_HOTs installed as described in the previous paragraph can be also used to feed a docking station for smart charging application. This docking station is made by 4-6 plugs-in which little size house appliances and electrical devices and battery charger can be connected. Thanks to a user-friendly interface (red/yellow/green LED light) and to a smart energy management system that is able to find the best strategy to satisfy all the requests, this docking station is able to show to the user when the power produced by the TEG is inviting to connect devices to be charged. Thanks to this device, the power produced by the belt_HOT could be easily exploited directly at home during the day and, thanks to a battery to store the whole day overproduction, it can be also used in the night to feed up to 10-12 LED lights, typically installed in the garden for security purposes. So TEG power is directly consumed at house avoiding as much as possible distribution losses, even if the power request is not as constant as in 3.1.1 option.

\subsection{Condo}

In this scenario a eight floors building is considered. In this building there are 30-40 flats, whose heating and DHW requests are satisfied by a centralized $500 \mathrm{~kW}_{\mathrm{t}}$ gas natural boiler. In this scenario, boiler installation needs to be carefully considered. If it is installed on the top of the building, the exhaust piping is quite similar to the $\S 3.1$ scenario, even if a larger diameter $($ e.g. $60 \mathrm{~cm})$ can be considered. If the boiler is installed in a special room in the basement of the building, a longer piping system can be considered, in order to exploit the exhaust waste heat. In this scenario the power produced by the belt_HOT TEGs aims to satisfy the lighting of the condo common spaces (hall, stairway, entrance, lobbies...). This power consumption can be estimated in $1 \mathrm{~kW}$ using 20 compact neon fluorescent lamps (CFL), 50 - 60 W each one, or in $500 \mathrm{~W}$ using 20 LED tube lamps, 25-30 W each one.

Basing on chimney geometry, it is supposed to use a belt_HOT realized coupling three rows of TEG with 40 cell per row. As in the previous scenario, the boiler has an operating period supposed in 2000 hours/year, related to a classical intermediate Italian climatic zone (Table 3) (Italian Governmental Decree... 1993). Looking at the power request and at the exploitable thermal gradient $\left(80-100^{\circ} \mathrm{C}-\right.$ fig.4), it is supposed to install 10 belt_HOT all along the evacuating piping in the presence of CFLs or 5 belt_HOT TEGs in the presence of LEDs. Such configuration, coupled with a battery to harness the overproduction, guarantees a continuous production of 500 $\mathrm{W}$ and $1 \mathrm{~kW}$ in these operating conditions with a $\mathrm{P}_{\max }$ supposed of about $600 \mathrm{~W}$ or $1,2 \mathrm{~kW}$. This application produce an energy saving of about $1000-2000 \mathrm{kWh}$ and a cost saving of 200-400 €/year.

Table 3. belt_HOT application coupled to high efficiency lighting in a condo (CFL lamp - LED lamps)

\begin{tabular}{|c|c|}
\hline belt_HOT configuration & 5-10 belt made by 120 TEG cells \\
\hline Total Pmax installed & $4,2-8,4 \mathrm{~kW}$ \\
\hline $\begin{array}{c}\text { Power Output with } \mathbf{\Delta T}= \\
\mathbf{8 0}^{\circ} \mathbf{C}\end{array}$ & $600 \mathrm{~W}-1,2 \mathrm{~kW}$ \\
\hline Total Year Energy Saving & $1000-2000 \mathrm{kWh}-200-400 €$ \\
\hline
\end{tabular}

Source: Italian Governmental Decree..

(1993) 


\subsection{Alpine Hut}

In an isolated alpine hut, biomass stoves are used for cooking and heating purposes. These kind of boilers evacuate flue gas from their chimney (typical diameter $20 \mathrm{~cm}$ ) at a temperature of about $200^{\circ} \mathrm{C}$, so a thermal gradient of $170-180^{\circ} \mathrm{C}$ can be exploited, even if the operating hours of these systems are significantly lower. Thanks to these higher values, the producibility of each TE cell approximately doubles (Thermonamic Co. 2014). In such situation, a battery to harness overproduction is necessary, extending the potential use of the electricity produced by TEGs as the operating hour period is related to the presence of guests in the hut.

Table 4. belt_HOT application coupled to biomass boiler in an alpine hut

\begin{tabular}{|c|c|}
\hline belt_HOT configuration & 4 belt made by 36 TEG cells \\
\hline Total Pmax installed & $1 \mathrm{~kW}$ \\
\hline $\begin{array}{c}\text { Power Output with } \boldsymbol{\Delta} \mathbf{T}= \\
\mathbf{1 8 0}^{\circ} \mathbf{C}\end{array}$ & $200-250 \mathrm{~W}$ \\
\hline
\end{tabular}

Source: Champier et al. (2010)

Installing 4 belt_HOT TEGs composed by three rows of 12 cells per row, a production of $200 \mathrm{~W}$ can be estimated with a $\mathrm{P}_{\max }$ supposed of about $250 \mathrm{~W}$, in accordance to the experimental results of Champier et al. 2010 (Table 4). The electricity produced by TEGs can be used directly by the guest to charge their electronic devices (and making possible to make an autonomous on-demand recharging station in the shelter) or to feed some LED lights installed in the hut.

This power production can also easily integrate the contribution from other renewable generators typically installed in this kind of resort, like PV panels or micro-wind generator.

\section{Conclusions}

This study describes a preliminary design of a low-cost thermoelectric generator, evaluating the power producibility and the energy saving that can be achieved in three different scenarios. For a simple and cheap application, commercially available modules have been tested and the performance of TE modules have been evaluated according to technical data sheet and previous research models and experiments. The main features of TEGs evaluated in this research are as follows, confirming other previous research results about TEGs' technoeconomical feasibility (Patyk 2013).

- The TEG is a heat recovery generator: it doesn't need any extra energy from the thermal source even if it converts only a small part of the heat flux into electrical energy (efficiency between $0,6 \%$ to $3 \%$ )

- The TEG can be easily incorporated in the structure of the heat source, i.e. the exhaust piping and the fluegas chimney in our research

- The generator produces whenever the boiler is on night and day and without weather implications, guaranteeing a continuous and autonomous production as the maintenance is very light

- Designing the TEG, a strong attention has to be considered to evaluate and manage the heat dissipation at the cold side of the TE cell studying heat sink and exchange in order to maintain $\mathrm{T}_{\mathrm{c}}$ and $\Delta \mathrm{T}_{\mathrm{TEG}}$ as much stable as possible.

- It is worthy to underline that, unfortunately, to produce a certain amount of power TEGs work with significant thermal gradient $\left(70-100^{\circ} \mathrm{C}\right)$, so this technology can't be coupled, for example, with more efficient heating system like condensing boiler which have an exhausts temperature of $40-65^{\circ} \mathrm{C}$ with a reduced exploitable thermal gradient.

The cost price has been briefly estimated as follows:

- The price of the Step Up Boost DC-DC Converter is $6 €$ for one sample and drops to 1-2 $€$ for more than 1000 samples 
- The price of one TE module is $10-15 €$ and it decreases to $5 €$ for 1000 samples. However the price of Peltier TE cooling modules of the same size produced in large quantities starts at 6-8 $€$ for one piece and decreases to 1 $€$ for 1000 pieces. As the production of Peltier modules uses the same materials and the same technology except for welding on the hot side (exploiting the same reverse effect) except for welding on the hot side it could be possible to use these cell with a little bit lower performances.

- The price of the heat sink and the thermal patch can be evaluated in 1-2 $€$ as this kind of components are typically used for electronic and computer purposes.

The total price of our qb_HOT TEG can be estimated around $50 €$, with a cost per Watt around 8-12,5 $€ / \mathrm{W}$ (depending on the exploitable thermal gradient). This initial cost is estimated to decrease towards $20 €$ per sample and $4 € / \mathrm{W}$, when a relatively small production line is started. Our study shows that the exhausts of traditional gas boilers can be exploited also for feeding high efficient devices like Smart Docking Station or LED lighting, making cogenerative all the thermal generators thanks to the TEG energy harvesting capability. Initially, it is envisaged that qb_HOT TEG would be assembled and tailored to the application, while, in a second stage, also the TEG cells could be locally manufactured and improved.

Future work will consist in testing the proposed TEG concepts on the field, coupling them to exhaust pipes and testing their performance also in presence of reduced thermal gradients, which are very frequent in everyday life.

\section{References}

Balkienė, K. 2013. Sustainable innovativeness: issues and public policy, Journal of Security and Sustainability Issues 3(2): 53-76. DOI: http://dx.doi.org/10.9770/jssi.2013.3.2(5)

Baublys, J.; Miškinis, V.; Konstantinavičiūtė, I.; Lekavičius, V. 2014. Aspirations for sustainability and global energy development trends, Journal of Security and Sustainability Issues 3(4): 17-26. DOI: http://dx.doi.org/10.9770/jssi.2014.3.4(2)

Bell, L.E. 2008. Cooling, heating, generating power and recovering waste heat with thermoelectric systems, Science 321:1457-61.

Bianchini, A.; Pellegrini, M.; Saccani, C. 2014. Thermoelectric cells cogeneration from biomass power plant, Energy Procedia 45: 268277.

Caurkubule, Ž.; Rubanovskis, A. 2014. Sustainable entrepreneurship through motivation: case of Latvian companies, Entrepreneurship and Sustainability Issues 2(1): 43-48. DOI: http://dx.doi.org/10.9770/jesi.2.1(6)

Champier, D.; Bédécarrats, J.P.; Kousksou, T.; Rivaletto, M.; Strub, F.; Pignolet, P. 2011. Study of a TE (thermoelectric) generator incorporated in a multifunction wood stove, Energy 36: 1518-1526.

Champier, D.; J.P.Bédécarrats, M.Rivaletto, F.Strub. 2010. Thermoelectric power generation from biomass cook stoves, Energy 35: 935942 .

Chien-Chou Weng, Mei-Jiau Huang. 2013. A simulation study of automotive waste heat recovery using a thermoelectric power generator, International Journal of Thermal Sciences 71: 302-309

Comitato Termotecnico Italiano - CTI - Italian Technical Normative UNI 10348: 1993 - "Riscaldamento degli edifici. Rendimenti dei sistemi di riscaldamento. Metodo di calcolo."

Garškaitè-Milvydienè, K. 2014. Anti-crisis management of enterprises and possibilities of overcoming their critical condition, Journal of Entrepreneurship and Sustainability Issues 1(4): 187-203. DOI: http://dx.doi.org/10.9770/jesi.2014.1.4(1)

Harb, A. 2011. Energy harvesting: State-of-the-art, Renewable Energy 36: 2641-2654.

Hsu et al. 2011. An effective Seebeck coefficient obtained by experimental results of a thermoelectric generator module, Applied Energy 88(12): 5173-5179.

Italian Governmental Decree. D.P.R. 26 agosto 1993 n.412 - "Regolamento recante norme per la progettazione, l'installazione e la manutenzione degli impianti termici degli edifici, ai fini del contenimento dei consumi di energia, in attuazione dell'art. 4 , comma 4 della legge 9 gennaio 1991, n.10" 
Kaminskienè, N.; Žalėnienè, I.; Tvaronavičienè, A. 2014. Bringing sustainability into dispute resolution processes, Journal of Security and Sustainability Issues 4(1): 69-77. DOI: http://dx.doi.org/10.9770/jssi.2014.4.1(6)

Laužikas, M.; Mokšeckienè. 2013. The role of creativity in sustainable business, Entrepreneurship and Sustainability Issues 1(1): 10-22. http://dx.doi.org/10.9770/jesi.2013.1(2)

Litvaj, I.; Poniščiaková, O. 2014.Entrepreneurship and quality management, Entrepreneurship and Sustainability Issues 1(4): $204-209$. DOI: http://dx.doi.org/10.9770/jesi.2014.1.4(2)

Mačiulis, A.; Tvaronavičienè, M. 2013. Secure and sustainable development: Lithuania's new role in taking the Presidency of the EU, Journal of Security and Sustainability Issues 3(2): 5-13. DOI: http://dx.doi.org/10.9770/jssi.2013.3.2(1)

Miškinis, V.; Baublys, J.; Lekavičius, V.; Morkvėnas, A. 2013. New Changes in Lithuanian Energy Sector, Journal of Security andSustainability Issues 2(3): 15-28. DOI: $\underline{\text { http://dx.doi.org/10.9770/jssi.2013.2.3(2) }}$

Murugavel, Raju. 2008. Energy harvesting, White Paper, Texas Instruments, November.

Nolas, G.S.; Sharp, J.; Goldsmid, H.J. 2001. Thermoelectrics: basic principles and new materials developments. New York: Springer. 2001

Nuwayhid, R.Y.; Rowe, D.M.; Min, G. 2003. Low cost stove-top thermoelectric generator for regions with unreliable electricity supply, Renewable Energy 28: 205-222.

OnSemi Conductor Ltd. 2014. NCP1406, NCV1406 25 V/25 mA PFM Step-Up DC-DC Converter Technical Sheet. Available online: < http://www.onsemi.com/> [Accessed 03 September 2014]

Patyk, A.2013. Thermoelectric generators for efficiency improvement of power generation by motor generators - Environmental and economic perspectives, Applied Energy 102: 1448-1457.

Peltier, J.C.A. 1834. Nouvelles expériences sur la caloricité des courants électrique [New experiments on the heat effects of electric currents], Annales de Chimie et de Physique 56: 371-386.

Prause, G. 2014. A holistic concept for the sustainable evaluation of company shares, Entrepreneurship and Sustainability Issues 2(1): 37-42. DOI: http://dx.doi.org/10.9770/jesi.2014.2.1(5)

Rakauskienè, O. G. 2014. Long term changes in the quality of life of Lithuanian population: 20 years in the market economy, Journal of Security and Sustainability Issues 4(1): 41-58. DOI: http://dx.doi.org/10.9770/jssi.2014.4.1(4)

Raudeliūnienè, J.; Tvaronavičienè, M.; Dzemyda, I. 2014.Towards economic security and sustainability: key success factors of sustainable entrepreneurship in conditions of global economy, Journal of Security and Sustainability Issues 3(4): 71-79. DOI: http://dx.doi.org/10.9770/jssi.2014.3.4(7)

Seebeck, T. J. 1825. Magnetische Polarisation der Metalle und Erze durch Temperatur-Differenz [Magnetic polarization of metals and minerals by temperature differences)] Abhandlungen der Königlichen Akademie der Wissenschaften zu Berlin [Treatises of the Royal Academy of Sciences in Berlin], 265-373.

Thermonamic Co. Ltd. 2014. Thermo-electric module generator - TEP 1-1264-15 Technical Data Sheet. Available online: <http://www.thermonamic.com/>. [Accessed 02 September 2014]

Tvaronavičienė, M. 2012. Contemporary perceptions of energy security: policy implications, Journal of Security and Sustainability Issues 1(4): 235-247. DOI: http://dx.doi.org/10.9770/jssi.2012.1.4(1)

Tvaronavičiene, M. 2014. If industrial sector development is sustainable: Lithuania compared to the EU, Entrepreneurship and Sustainability Issues 1(3):134-142. DOI: http://dx.doi.org/10.9770/jesi.2014.1.3(2)

Tvaronavičienè, M.; Šimelytė, A., Lace, N. 2014. Sustainable development facets: exporting industrial sectors from inside, Journal of Security and Sustainability Issues 3(4): 37-44. DOI: http://dx.doi.org/10.9770/jssi.2014.3.4(4)

Vasiliūnaite, R. 2014. Sustainable development: methodological approaches toward issues, Journal of Security and Sustainability Issues 3(3): 69-75. DOI: http://dx.doi.org/10.9770/jssi.2014.3.3(6) 
Vosylius, E.; Rakutis, V.; Tvaronavičienė, M. 2013. Economic growth, sustainable development and energy security interrelation, Journal ofSecurity and Sustainability Issues 2(3): 5-14.DOI: http://dx.doi.org/10.9770/jssi.2013.2.3(1)

Vuller, R.J.M.; Van Schaijk, R.; Doms, I.; Van Hoof, C.; Mertens, R. 2009. Micropower energy harvesting, Solid-State Electronics 53: 684-693.

Wang, Y.; Dai, C.; Wang, S. 2013. Theoretical analysis of a thermoelectric generator using exhaust gas of vehicles as heat source, Applied Energy 112: 1171-1180.

Stefano BARBERIS was born in Genoa in 1988. He obtained his Master Degree in Mechanical Engineering at University of Genoa in2012 with the Thesis "Thermoeconomic Analysis and Optimization of Innovative Concentrating Solar Power Plants". He joined TPG as PhD student in 2013

Lorenzo DI FRESCO, born in Genoa in 1975, obtained the Degree in Mechanical Engineering at the University of Genoa in 2002. He worked in the Industry as Manufacturing Engineer dealing with production efficiency and quality management issues being beside a ISO 9001:2000 quality management system assessor. He joined the TPG in 2008: his activity focused on the thermoeconomic analysis of renewable energy systems, and on the study of energy buildings certification standards development: he is a qualified energy assessor accredited by Liguria region. He obtained his Ph. D. on the Seaspoon, an innovative Ocean Energy device for distributed microgeneration.

Vincenzo Alessandro SANTAMARIA was born in Genoa in 1985. He obtained his Master Degree in Informatics Engineering at University of Genoa in 2012 with the Thesis "Techniques of variables selection for sensor diagnostic: application to a micro gas turbinebased test rig". He joined TPG (Thermochemical Power Group) of the University of Genoa in 2012 as temporary research fellow. He carries out research about the control and monitoring system of Seaspoon, an innovative Ocean Energy device for distributed microgeneration. Now he works with TechCom, an innovative informatics Italian start-up.

Alberto TRAVERSO is Associate Professor of Energy Systems for Mechanical Engineering. He obtained the Ph.D. in 2004 with the thesis "TRANSEO: A New Simulation Tool for the Transient Analysis of Innovative Energy Systems". His main field of expertise is the time-dependent analysis of energy systems, including fuel cell hybrid cycles. He is also responsible of WTEMP software development for thermoeconomic analysis of innovative energy systems. He is part of the steering committee at TPG for the Rolls-Royce Fuel Cell Systems Ltd UTC.

This is an open access journal and all published articles are licensed under a Creative Commons Attribution 4.0 International License 